\title{
Architecture in the Anthropocene: The Notre-Dame de Paris Fire and the 'Force' of 'Culture'
}

\author{
Susanne Krasmann
}

Architecture exceeds the distinction between the cultural and the natural. It is an artefact that deploys its own force, and thus points us to our relatedness. By way of a thought experiment, the article introduces architecture as a fellow being into the Anthropocene debate, one that helps us reconsider our human situation. Using the example of the public reactions to the Notre-Dame de Paris fire in 2019, it explores how architecture itself appears as a cultural force. It affects the life and the togetherness of people; it encourages us to conceive of society in material terms as a multiplicity that involves our senses and sensitivity; and it reminds us of how creative and destructive forces are interwoven.

Keywords: affect; Anthropocene; architecture; collectivities; destruction

\section{Culture and Humanity in the Anthropocene}

When the coronavirus arrived early in 2020, the pianist Igor Levit started a series of recitals on Twitter. While cultural institutions were shut down and people forced to stay at home to avoid contact, they could watch his solo concerts of classical music, starting at $7 \mathrm{pm}$ each evening. There was no prescheduled programme, and Levit decided what to play every day, depending on his mood: Beethoven, Bach, Shostakovich and others. In his self-description on Twitter, the pianist quotes Leonard Cohen: 'There is a crack in everything. That's how the light gets in. ${ }^{1}$ The concerts soon became an institution, and although they could be retrieved afterwards on the internet, it was important to attend on time. Similar performances followed during the pandemic: live concerts taped without audiences in concert halls were streamed, and thanks to a sophisticated technique virtual choirs and orchestras managed to perform their music as a joint project online. To be part of this was comforting: it gave people the feeling they were not alone, but it was also driven by the desire to live and to connect, in a Deleuzian sense, to experience life through the stimulation or expansion of one's own senses. Or as Georg Simmel famously observed, human beings rely on 'culture' as that which brings them to 'unfold' as a subject in the first place: 'Culture is the way that leads from the closed unity through the unfolded multiplicity to the unfolded unity' (Simmel 1968: 29). Early sociology reminds us of human beings' relatedness, where 'culture' begins with our working on things, with 'cultivation' that gives things, life or certain materialities, a form (Kraemer

University of Hamburg, DE

susanne.krasmann@uni-hamburg.de
\& Bredekamp 2013: 21). Culture thus cannot be separated from the 'matter' it is dealing with, and in Simmel's view it is also what constitutes our subjectivity. It is a precondition of our individuation (Lambropoulos 2001).

While the coronavirus pandemic kept the world in a state of suspense, we were forced to realise that its outbreak was a further confirmation of the Anthropocene thesis (Birrell \& Lindgren 2021) demarcating a rupture with our previous comfortable belief in a relatively stable ecological system and humans' 'capacity to take all the world as [their] own' (Colebrook 2012: 197). As modernity and civilisation have once again come under scrutiny, it is impossible to miss the eschatological undertone of extinction and finitude this time (Rothe 2020). Beyond the familiar critique of instrumental access to the world, including extractive capitalism and (post-)colonial violent politics, humanity sees itself urged to radically resituate itself in view of the life on earth it has irrevocably altered (Chakrabarty 2009). At this moment when the aggregated behaviour of the human species as a whole reaches truly cosmological proportions' (Chernilo 2017: 47), anthropocentrism is under increasingly intense scrutiny. How can we re-imagine a world and an ethics that enable us to dismiss the destructive force of human politics (Colebrook 2012), and how can we avoid resuming a sovereign gaze in the aspiration to tell how the world essentially is as it is, or should be, in ignorance of 'the limits of human representation' (Colebrook \& Weinstein 2017: xx)? As the ontological problem of what is cannot be separated from the epistemological endeavour of fundamental selfreflection (Foucault 1989), a post-humanist move does not appear to be a prospect. Rather than giving up the idea, the true challenge consists in assuming humanity as being 'both necessary and impossible' (Colebrook \& Weinstein 
2017: xxiv), that is, as a mode of existence we cannot but presume in order to undermine it.

If to ask how humans are situated in the world and relate to their fellow beings is a genuinely modern motif, the Anthropocene thesis reinforces it by stressing that in fact we rely on others to exist. Corresponding research strategies that focus on 'the nature of entangled being' (Chandler 2018: 20) range from dismantling 'asymmetric' modern distinctions, such as between human beings and things, biological life and 'ecological milieu', 'artificer' and 'art-efact' (Ingraham 2006: 8; Tsing 2015) to granting non-human, or rather 'more than human' (Whatmore 2002: 159) beings their own rights. ${ }^{2}$ In this situation, I'd like to direct attention towards a different 'fellow being': namely, architecture. Architecture can be considered paradigmatic here, as it eludes the distinction between the natural and the cultural. As an artefact, it is not something just there at hand, nor can it be reduced to an object created by human beings. Architecture, it will be argued, from the first moment of its existence takes on a life of its own: of acquiring space and establishing spatial relationships, of unfolding an atmosphere we sense when we enter a building, of breathing as different materialities communicate with each other, of breaking and distributing the light in its interior in a particular manner, or of allowing moss to grow on it when abandoned to corrosion and decay, to the 'downward-dragging [...] power of nature' (Simmel 1958: 381). Architecture deploys its own force and it 'responds to forces in the world' (Ingraham 2006: 9). It affects us, not only in the ways we are able to move or see, but also in that we admire it and feel attached to it. It points us to our relatedness.

It is in the debate on architectural heritage that the question of the importance of architecture is most prominently being discussed on a global scale. More often than not this question is considered as one of representation and hegemony, and architecture is deemed to assume an 'ethical function' (Harries 1997): in what it means to a particular people and how it constitutes their identity. This perspective easily feeds into an identity politics (Brosché et al. 2017) that carries its mission of architecture symbolising a particular 'culture' or 'civilisation', dissociated from, and sometimes at the cost of, other collectivities. ${ }^{3}$

In the following, a different perspective will be brought into play. As the example of the fire that damaged NotreDame Cathedral in Paris in 2019 suggests, there is a sense of belonging to architecture, a form of attachment that people cherish, which exceeds established cultural scripts and wordings addressing, for example, national pretensions. After a brief look at how the current heritage discourse problematises contested architecture, an affect-theoretical perspective will be explored in order to incorporate the sensual or corporeal dimension in the analysis of our relatedness. Conceiving of architecture itself as a force, rather than merely a cultural object, is to push Simmel's observation of the indispensability of 'culture' for our social existence to the present moment. This gesture may well be understood as a thought experiment, one that will lead us to the nexus between creative and destructive human forces, i.e. of inventing, designing, erecting, fighting for and destroying artefacts. Architecture, it will be argued, reminds us that we do not, and never did, 'own' the world.

\section{Architectural Heritage Contested}

Architecture has a long tradition of being admired as 'the most precious of inheritances', as John Ruskin (1849: 245), spiritus rector of the international movement for the preservation of architecture, famously put it. Architecture is able to connect space and time, 'place and memory' (Silverman 2015: 71), and it promises perpetuity (see Barshack 2010: 219). It is believed to be sturdy and solid, and to outlive generations, though it is also fragile (Holtorf 2014), subject to demolition and decay. In its material presence as a form of art, architecture tends to be seen as a conspicuous manifestation of the best capabilities of humanity. Its destruction, accordingly, is perceived as a failure, a humiliation of 'the will of the spirit' (Simmel 1958: 379) and an annihilation of the sublime human imagination and creativity. ${ }^{4}$

Architecture figures as an object of desire and pride, but also of power and fear. It has been identified as a vehicle of domination, with a history of signifying authority and constituting sovereignty (e.g. Barshack 2010; Smith 2011). Prestigious buildings, such as the Palace of Westminster in London, are supposed to speak of a glorious past that extends to the present (see Jones 2020: 67). Indeed, architectural sites are not just inheritance, they are made the heritage of a particular culture or people (see Silverman 2015: 71; Trimm 2018). And heritage politics has been blamed for fostering our desire for the 'good life' architecture allegedly symbolises, while other buildings, and with them the everyday life of the people, are neglected and turned adrift (Kalaycioglu 2020: 2; Stoler 2016).

Famously, it was Georges Bataille (1998: 37) who saw in architecture 'the expression of the very being of societies' and their values, but mainly its intimidating, subjecting effect (see Ballantyne 2005: 5). Monumental buildings such as cathedrals and palaces, in Bataille's view, are materialisations of power 'to impose silence on the multitude' (ibid.: 16). However, one can reasonably doubt whether architecture actually 'speaks' a language and expresses meaning other than that which is attributed to it by human beings. It is not surprising, therefore, that the value and meaning of architecture is time and again subjected to contestation. In revolutionary Paris, for example, the statues of the 'gallery of kings' above the main entrance to Notre-Dame, deemed to represent the twenty-eight Kings of Judah, were identified as symbols of despotic power and decapitated. It is the act of destruction itself that imposes the meaning (Weizman \& Hersher 2011).

In recent years, architecture has increasingly come under attack and been contested on a global scale. The destruction of historical sites such as in Palmyra, Syria, or Timbuktu, Mali, has been perceived not only as a symbolic attack on a particular culture but also as a form of violence against a particular people, as the negation and annihilation of their mode of existence (Autenrieth $\&$ van Boekel 2019). ${ }^{5}$ The destruction of the Bamiyan Buddhas by 
the militia of the Taliban regime in 2001 in Afghanistan is considered a signature event in this respect (see Lostal 2017a: 122). As a reaction, the UNESCO Declaration on the Intentional Destruction of Cultural Heritage, issued in 2003, in its preamble deplores 'the tragic destruction of the Buddhas of Bamiyan that affected the international community as a whole'. ${ }^{6}$ The international public outcry thus raised the general question of 'the degree to which "other people's heritage" is also part of one's own' (Gillman 2010: 12).

The recent heritage discourse enjoys a growing awareness of cultural diversity and the protection of local values and practices, as well as of natural entities. This is said to have been fostered by the success of the human rights discourse, and then extended into calls for the containment of environmental degradation (e.g. Franconi \& Lixinski 2017; Philippopoulos-Mihalopoulos 2017). It has informed political agendas and has also helped to encourage respect for a number of cultural rights and rights of nature. ${ }^{7}$ Of particular interest for our present context are two further developments. First, in the endeavour to protect World Heritage, a general move can be observed away from a rather 'monumentalist vision' towards 'more incorporative' approaches that include 'natural sites and places of anthropological, aesthetic, and ethnological importance' (Hammer 2018: 9; Arregui et al. 2018; Turpin 2013). In its ambition to bring about 'common worlds' and 'common futures', a perspective of 'ontological plurality' (Harrison 2015) or 'relational ontology' (Harrison 2013) subjects the distinction between the natural, the cultural and the human itself to critical inquiry. Second, the notion of the 'whole of humanity' currently seems to achieve new meaning. Recent research has shown how the recognition of cultural objects as World Heritage in the practices of negotiating and producing the societal valuable leads to an alliance between, not the juxtaposition of, the universal and the particular: the particular is made universal (see Schäfer 2016: 355). It has also been argued that architectural heritage cannot be monopolised by anyone as it embodies a value 'per se' (Lostal 2017a). This insistence appeals to - and advances - an early legal figure of the heritage discourse claiming 'that damage to cultural property belonging to any people whatsoever means damage to the cultural heritage of all mankind'. ${ }^{8}$ It resonates with a key figure of thought in the Anthropocene debate: something - nature or cultural objects - that has been touched - created or damaged by human beings henceforth deserves its independent existence, as a way of showing respect to its waywardness (see Krasmann 2019: 3).

Speaking of architecture in the present context refers to significant buildings, though not so much in the sense of their officially being recognised as 'art' or cultural heritage by national or international institutions such as UNESCO. The question rather is how people, or societies, in one way or another feel attached to architecture and claim it to be significant for them. Architecture, then, is more than houses or buildings: it is the togetherness of concept, form, invention, material, inhabitation, presence. It entails objects like churches and mosques, statues and monuments, urban facades, sites and arrangements, and it has one more crucial characteristic: it is public. It allows for a projection of what people share, their commonality, and what they are and could be. Today we can tell how Confederate monuments in the southern states of America, for example, are sources of pain for many African Americans; or how the images of the Grenfell Tower fire in London reminded people of the residents' lives lost as well as of a politics of systematic neglect that led to the disaster in 2017. As we will see in the case of the Notre-Dame fire in Paris, architecture does not just represent commonality but also provides the imaginary and material space to articulate it (see Schwarte 2009: 205-6).

\section{Affective Architecture}

On April 15, 2019, a fire that lasted around 15 hours ravaged Notre-Dame Cathedral in Paris. The major part of the cathedral's roof was consumed by the flames and the iconic spire, an architectural addition of the 19th century, spectacularly collapsed a few hours after the fire was initially noticed, while the interior and the basic structure of the building, thanks to the professionalism of the Paris Fire Brigade, remained largely intact. Particularly striking was the spontaneous gathering of people on the banks of the Seine, watching and mourning the inexorable destruction of the cathedral, and the international outcry at the devastation of one of Paris' most famous landmarks, regardless of nationality or religious background. During the inferno, a young woman in the crowd could be heard saying: 'It's just heartbreaking to see these centuries of history and culture go up in smoke.'

Politicians praised the ancient building not only as an expression of French or European culture and history, but as something that 'belongs to the whole of humanity'. As the then president of the EU Commission Jean-Claude Juncker underlined: Notre-Dame 'has inspired writers, painters, philosophers and visitors who have come from all round the world.' On Twitter, former US president Barack Obama described Notre Dame as 'one of the world's great treasures', and Michelle Obama said: 'The majesty of Notre-Dame - the history, artistry, and spirituality - took our breath away, lifting us to a higher understanding of who we are and who we can be.' German Chancellor Angela Merkel's spokesperson said the images of the cathedral on fire were 'painful'. ${ }^{10}$ More sophisticated comments could be read in newspapers and magazines, for example, by Agnès Poirier writing in the New York Times: 'Notre-Dame has always been much more than a cathedral or a historical building. She is a living being, an imposing yet benevolent presence in the life of anyone who approaches her.' ${ }^{11}$

Christopher Caldwell attributed people's attachment to the cathedral, so visible on the night of the fire, to the fact that the building embodied 'realities that many people regret being cut off from':

The fire at Notre-Dame is harrowing in a way that feels religious because it is religious: It forces us to understand France as those who created it understood it. The people weeping on the banks of the 
Seine must have sensed this, even if they could not put into words exactly what they were weeping over. $^{12}$

Columnist Roger Cohen even compared the preciousness of the cathedral with the value of human life: 'The loss of human life is terrible to behold, but the destruction of beauty may be no less so.'13

Without hesitation, President Macron promised to 'rebuild Notre-Dame Cathedral', in view of the upcoming Olympic Games within five years, and 'more beautifully than ever'. A modernised spire would add a 'contemporary architectural statement'. ${ }^{14}$ Norman Foster applauded the president's plan, calling it 'an acknowledgment of that tradition of new interventions and a pledge for its continuation.' ${ }^{15}$ A fundraising campaign was quickly initiated and was said to have raised over $€ 1$ billion within a week, but critical voices were also raised. The yellow vest movement (Mouvement des gilets jaunes) protested, 'Everything for Notre Dame, nothing for the poor,' and climate activists adopted the slogan 'Save our planet, not Notre Dame. ${ }^{16}$ In her speech to the European parliament on the day after the fire, Greta Thunberg in her own way called for 'cathedral thinking' when tackling climate change: 'We must lay the foundation while we may not know exactly how to build the ceiling.' ${ }^{17}$

It is remarkable how these comments, apart from any imaginable political calculus, evoke a corporeal experience: it is 'heartbreaking to see these centuries of history and culture go up in smoke'; Notre-Dame in her 'imposing yet benevolent presence' is a living being; 'cathedral thinking' demarcates the indispensable foundation for building a global future. Even President Macron's assertion that the reconstruction would start immediately can be read as a form of affect modulation to reinvent a community, with the 'contemporary architectural statement' indicating a will to renewal. The yellow vest protesters, in turn, played their own economic, and ultimately physical, existence off against what they considered, by comparison, a dispensable cultural value. Obviously, the appreciation of Notre-Dame cannot be reduced to the rather static logic of representation, such as the cathedral being a symbol of 'our' culture or civilisation. Rather, the inferno evoked a collectivity that showed itself to be emotionally and physically attached to the building in such a way that it seemed to be intertwined with their very human bodies. As chief architect of the cathedral Philippe Villeneuve put it, 'We will do everything we can to heal this wounded marvel. She is hurt, but so are we.'18

How architecture shapes societies and how people appreciate certain buildings can only partly be observed empirically in the practices of its usage. Feelings of attachment remain rather tacit. In everyday life, architectural sites tend to receive little or no attention, even if considered important. People pass by without looking at the edifices, let alone inspecting their architectural details (see Veyne 1988: 2). Official heritage listings or theories of art in turn offer only distillations of the valuable, while tourist visits are often overdetermined by cultural readings. Architecture, Heike Delitz maintains, may be expressive, but it does not represent anything: there is no object that it designates beyond itself (2010: 193-4). And it is itself not just an object that can be reduced to its figurative forms and merely read cognitively and symbolically (see e.g. Goodman 1978). It appeals to a multiplicity of our senses. The notion of affect is key to capturing this relationship that societies entertain with architecture in material and sensual terms. Affect does not reside in somebody but is what happens between bodies (Ahmed 2010). It may be induced in the encounter with architecture, where people feel 'touched' by its appearance. As Paul Veyne points out, 'far from conveying an iconography or an ideology' (1988: 2), architecture 'proves the existence of a social force' that presents itself 'in front of time rather than in front of men'. Monuments 'are not messages to someone else nor the ideal expression of humanity, even less the visage of society. They express the power that made them rise from the earth.' (ibid.: 11)

Architecture that inspires us and engages our imagination also draws a line between what is, and can exist, and what is impossible or illusory, and cannot materialise (see Schwarte 2015: 37-8). As a 'mural fold' (Seitter 2002), it divides - spatially, visually and symbolically - what is inside from what is outside and thus even shapes expectations and beliefs (see Delitz 2010: 20; 2018). If the Gothic cathedral, for example, is seen as a particular manifestation of a religious belief that connects 'body and soul', it is the lean and tall architecture itself, its mode of suffusing matter with light and of reaching out to a public space, that renders the 'spirituality' tangible (see Schwarte 2009: 185). It produces, so to speak, its own believing, or fascinated, subjects (see Delitz 2010: 79).

Gilles Deleuze and Félix Guattari (1994) consider architecture 'the first of the arts' due to its peculiar capacity, as 'houses', to set 'frames'. Architecture encourages us to move, as we experience the shifting framings and compositions of the window, the wall and the floor. It activates our senses in the way in which different 'planes and sections' are joined up, interlocked, set counterpoints, decompose, or deframe, and thus open up 'lines of flight' (ibid.: 186-7). It is through such movements that affects and resonance are invoked and intensified (Delitz 2010), and particular forms of attachment, understood as 'an enduring affectional bond' (Scheidecker 2019, 73), emerge and settle (see Ahmed 2014: 11): as we learn to inhabit that space and attribute meaning to it (Ahmed 2010).

As the public reactions to the Notre-Dame fire suggest, however, it was in and through that event that people appeared to be moved. It is in such situations of vulnerability, of exposure to damage or loss (Hentschel \& Krasmann 2020), that modes of attachment to architecture become particularly palpable - literally felt and articulated - and where the unexpected and perhaps existential moments of what organises societies or communities becomes apparent: the places where people assemble and bring about a matter of concern (Latour 2005; Weizman 2014); where they gather and reach out to each other in shock or worry, grief or awe, and thus forge a 'community of sense' (Hinderliter et al. 2009; Hutchison 2016); and where they dispute about whether and how to reconstruct a ruined building, and thus envision their own future and constitute themselves as such a collectivity. Rather 
than presuming given entities or pre-given 'borderlines between humans and things' (Lemke 2015: 15), what comes into view in an affect-theoretical perspective is how connections are made and how connectedness is sensed; how, in other words, we are 'allied with the world' (Grove 2014: 369) in such a way that when a building like Notre-Dame is destroyed we feel 'hurt' as well.

To be sure, such events are shaped by cultural scripts that provide framings of perception and dispositions of collectiveaction and thus make the concrete manifestations of architecture possible (see Schwarte 2009: 179-80). In the situation of the fire, Notre-Dame de Paris, not least thanks to its treatment in painting, literature and film, was already a cultural icon, perhaps even a myth in Roland Barthes' (1972) sense. As Adam Gopnik, a New Yorker staff writer, points out, Victor Hugo's (1831) novel Notre-Dame de Paris placed the cathedral in 'the quintessential French romantic setting': 'Quasimodo's love for Esmeralda is set in and around Notre-Dame precisely because the sheer power of life's irrational forces is felt so deeply there.' ${ }^{19}$ As the comments quoted above illustrate, the fire created a situation in which such imageries and cultural readings might have been evoked and revitalised, but in their actualisation they also assumed new forms, without ever fully capturing what makes for the aura of Notre-Dame. Caldwell is therefore probably right when he maintains that it was the unavailable that touched people: 'The bitter truth is that these old things are what is most impressive and special about France, partly because they have been "consecrated" by age but also because they embody realities that many people regret being cut off from. ${ }^{20}$

But why should we insist on the relevance of significant architecture such as Notre-Dame even in times of existential crisis, when humanity truly seems to have surpassed the limitations of intervening in and modifying the forms of life on earth? Drawing on Claire Colebrook's (2012) work, two motifs of the Anthropocene debate will give us some further clues, namely how we conceive of ourselves as related beings and what the question of life on earth might mean today.

\section{Anthropocene Thinking in Architecture}

If we are faced, today perhaps more than ever, with the challenge of overcoming an anthropocentric view, this does not leave us with the option of renouncing human subjectivity. Instead, Colebrook (2012) argues, we should retain our sense of thought as that which exceeds our existence in a double sense. Basically, thought is humans' ability to challenge the taken-for-granted; it may put us in the position to recognise our own 'malevolence' and ongoing 'detachment' from our fellow beings. Yet thought also refers to texts and theory, which deploy their own anonymous force, not owned by anyone, capable of making connections and of dislocating meaning (ibid.: 199). ${ }^{21}$ Rather than designating the autonomous Cartesian subject, thought reminds us of our inscription into this world, including our destructive forces. There is no final relief, no transcending escape from this predicament (see ibid.: 207). Becoming aware of our relatedness, as Judith Butler (2020) admonished us recently, might lead us to recognise that exercising violence, even with the intention of self-defence, is also violence against ourselves as social beings: it calls into question and ultimately cuts off the very possibility of being together, and thus of being in the world. However, from architecture and specifically from the Notre-Dame fire, we might learn something slightly different.

Architecture is a form of making connections as well. As it asserts itself in its material and, perhaps, proud existence, and as it affects us, architecture unfolds its own force. It may be a force without intention, but one that makes a difference (Povinelli 2016). If architecture in turn needs the 'will to construction' (Gafijczuk 2013: 160) and craftsmanship to be erected in the first place, humans are still not the autonomous originators. Not only does the specific type of material impose a form of resistance that requires a related mode of cooperation (see Latour 2013: 228); ultimately, it also guides craftsmanship and inspires creativity. Hence, even the design of architecture does not start from scratch but develops gradually over the course of human experience with building edifices (Ingold 1983). And there is more than that. It was the event itself that incited, literally inflamed the feeling of attachment to Notre-Dame de Paris. In its upward- and downwarddragging' force, the spectacular fire made people see and feel the loss of their treasure, the beauty and history that the cathedral not only represents but embodies, just going up in smoke. What had been ignored, taken for granted, beforehand: the grandeur of the cathedral, its aura, and the cultural knowledge surrounding it, now entered the collective senses - and the public scene. People constituted themselves as cultural subjects in the moment of devastation and destruction, and it was in this situation that they also brought 'a culture to bear on' the building (Ballantyne 2002: 49). Architecture, in this sense, itself is what 'occurs' (Crouch 2015: 178). In its cultural meaning, its societal value and even its shape it is not stable but happens to unfold 'into worlds' (Ahmed 2010: 30).

Construction, creativity and even maintenance, we might now realise, are intrinsically interlinked with destruction. As Ludger Schwarte (2015: 38) observes, already at the time of its foundation architecture acquires its own space, and destruction, displacement, and replacement are often conditions for it to be established and rendered visible and seeable from a distance, so that it can display its appearance. ${ }^{22}$ Moreover, if destruction is a prerequisite to establish an entirely new situation, construction such as the addition of an element like a new spire on the roof of Notre-Dame - may also destroy or disturb the previous constellation. This is how President Macron, with his promise to rebuild Notre-Dame more beautifully than ever, also identified an opportunity for societal renewal: 'I truly believe that it is up to us to transform this disaster into an opportunity to come together'. ${ }^{23}$ Similarly, French prime minister Edouard Philippe called for a fresh look with 'a new spire that is adapted to the techniques and the challenges of our era'. ${ }^{24}$ Indeed, the government's announcement of a competition for the rebuilding of the roof and spire instantly prompted architects to unleash their creative minds. Among the more far-fetched design proposals was a swimming pool that would occupy the whole roof of the cathedral and end the debate on the 
replacement of the spire with a novel architectural gesture, without imposing a new architectural stamp. Apart from the insinuation that it would provide the water for the next emergency, this idea paid tribute to the possibility of 'a complementary spatial experience to the building', guarded by the twelve statues of the apostles, 'with unmatched views over Paris'. ${ }^{25}$ Such ideas, to be sure, would not meet with the approval of UNESCO, which soon demanded that care should be taken over any changes to the character of the World Heritage site; but they are an indicator of the desire to enjoy the sacred building in its setting in full immersion.

Still, internet images of empty cities across the world during the coronavirus lockdown in 2020 may have given us an idea of what orphaned architecture looks like. ${ }^{26}$ How can we imagine the value of architecture to be independent of the human eye? 'What is scandalous,' Colebrook writes, 'is not [just] that humans have placed their own survival as more valuable than other lives' but how especially the tradition of Western thinking has determined what counts as valuable life, namely that which is either able to sustain itself or capable of giving life a 'form and definition'. Life as a form of cultivation that is deemed to flourish is defined in a circular form: 'we value life because it is life that makes value possible' and we think that 'destruction and annihilation are other than life and therefore unacceptable' (2014: 203, emphasis in original). It is against this background that we might begin 'not to ask about the value of human life for humans but of human life for life' on earth (ibid.: 205); and to recognise that 'life' is not just the 'vitality' of any matter (Bennett 2010) nor just what 'pertains to specific bodies' (Lemke 2015: 15) but what emerges out of the complex conjunction and interference of differential forces which may also bring it to exhaustion and extinction. Life is also exposure to destructive forces.

While Simmel (1968) considered 'culture' a necessary condition for the formation of the subject, what puzzled him was that culture defined as an objectified world also signifies a threat to individual subjectivity. It constitutes the experience of heteronomy and speaks of a subject that is not the subject of his or her world. This, for Simmel, was the 'scandal of the form' (Lambropoulos 2001: 235). Today, we can embrace this intuition as 'culture' points us to ourselves as subjects who do not own themselves. It reminds us of the crack that allows the light to get in. While being comparatively massive in its materiality, something remaining that cannot just be switched off, architecture shares with music, as a medium, the experience that it makes possible: of encounter, of atmosphere evolving and of the oscillation between inside and outside (see Fischer 2017: 59). This is why the desire for 'culture' became so palpable in the situation of confinement and solitude during the pandemic. It is what keeps us alive. To be sure, culture, thus understood, does not straightforwardly lead to the 'cultivated person', and it does not exclude barbaric acts (Adorno 2009). But if we want to retain some of these observations for the idea of the 'whole of humanity', we might bear in mind that it exists only in coexistence with a multiplicity of beings populating the world; and that it emerges out of a multiplicity of forces. This does not mean endorsing a neoliberal celebration of diversity and call for permanent effort, but rather, in concert with Anna Tsing's (2015) observations, it reminds us of the precarity of life - and 'culture'. As a non-homogeneous though still articulable entity, we may envision humanity as being like polyphonic music, which receives its uniqueness through the different temporal rhythms and trajectories interacting and collaborating with each other (see ibid.: 24) - and only in such moments of movement and affectation. Humanity is not just there, and we cannot rely on it. It has to be lived, filled with meaning and life, made in the now, as 'the future is not a place somewhere or sometime else' (Povinelli 2016: 137).

\section{Notes}

${ }^{1}$ Retrieved from https://twitter.com/igorpianist.

${ }^{2}$ On the relevance of social anthropology to conceiving of legal personhood as being embodied, see Vatter \& de Leeuw (2019); on an approach to affective attunement to nonhuman, or 'more than human', others that takes up 'indigenous cosmologies' in a project of extending sociopolitical membership, see Kwek \& Seyfert (2017).

${ }^{3}$ On related connotations of the German concept of culture and the French or English idea of civilisation, see famously Elias (2000).

${ }^{4}$ See S. Zekri (2019, April 18/19): Paris, was nun? [Paris, what next?], Sueddeutsche Zeitung, p. 1.

${ }^{5}$ For detailed case studies on the recent destructions of World Heritage sites in the context of armed conflict, see Lostal (2017b).

${ }^{6}$ Retrieved from: http://portal.unesco.org/en/ev.phpURL_ID $=17718 \& U R L \_D O=D O \_T O P I C \& U R L \_S E C T I O$ $\mathrm{N}=201$. html.

7 The UNESCO Convention for the Safeguarding of the Intangible Cultural Heritage, Paris, 17 October 2003, is a milestone here (retrieved from https://ich. unesco.org/en/convention). Equally important was the revision of the UNESCO Criteria for Selection of World Heritage Sites (Operational Guidelines), from 2005 onwards, to incorporate the definition of one set of ten criteria for both cultural and natural sites (retrieved from http://whc.unesco.org/en/criteria/).

${ }^{8}$ See the Preamble of the Convention for the Protection of Cultural Property in the Event of Armed Conflict with Regulations for the Execution of the Convention 1954, The Hague, 14 May 1954 (retrieved from https:// unesdoc.unesco.org/ark:/48223/pf0000082464). In its Article 1 it also emphasises that the term "cultural property" shall cover, irrespective of origin or ownership'.

${ }^{9}$ C. Wilkens (2019, 16 April). 'It's a funeral': Tears, prayers and shock as Paris mourns Notre-Dame. Retrieved from https://www.france24.com/en/20190416-notredame-funeral-tears-prayers-hymns-paris-mourns.

10 World 'watches and weeps' as Notre-Dame burns. France 24 (2019, 16 April). Retrieved from https:// www.france24.com/en/20190416-world-watchesweeps-notre-dame-cathedral-fire-france-paris. 
${ }^{11}$ A.C. Poirier (2019, 16 April). Standing Vigil for NotreDame. I watched the cathedral burn. Then despair was replaced by timid hope. New York Times. Retrieved from https://www.nytimes.com/2019/04/16/opinion/ notre-dame-fire.html.

${ }^{12}$ C Caldwell (2019, 20 April). Why Did Nonbelievers Grieve for Notre-Dame? Religion goes on, whether or not people honor its traditions. New York Times. Retrieved from https://www.nytimes.com/2019/04/ 20/opinion/sunday/notre-dame.html.

${ }^{13}$ R. Cohen (2019, 16 April). A Cathedral for a Fragile Age. The centuries made Notre-Dame everyone's. Never has French civilization felt more important. New York Times. Retrieved from https://www.nytimes. com/2019/04/16/opinion/notre-dame-cathedralfire.html.

${ }^{14}$ A. Nossiter (2019, 16 April). In Aftermath of NotreDame Fire, Macron Urges Unity in Fragmented Nation. New York Times. Retrieved from https://www.nytimes. com/2019/04/16/world/europe/notre-dame-fireinvestigation.html.

15 G. Voien (2019, 20 May). These 7 Proposals to Redesign Notre-Dame de Paris Are Meant to Start a Debate. Architectur + Design. Retrieved from https://www. architecturaldigest.com/story/proposals-redesignnotre-dame-de-paris-start-debate.

${ }^{16}$ Z. Juliusson (2019, 4 May). Save our planet, not Notre Dame. Rubicon online. Retrieved from https://www. rubiconline.com/save-our-planet-not-notre-dame.

17 Thunberg's speeches are available at: https://www. fridaysforfuture.org/greta-speeches\#greta_speech_ jan25_2019.

18 Arte Documentary (2020, 16 January). Visite du chantier de Notre-Dame de Paris. Retrieved from https://www.arte.tv/fr/videos/094894-000-A/visitedu-chantier-de-notre-dame-de-paris (my translation).

19 A. Gopnik (2019, 16 April). Notre-Dame in the French Imagination. The New Yorker. Retrieved from https:// www.newyorker.com/news/daily-comment/notredame-in-the-french-imagination.

${ }^{20}$ Caldwell, op.cit.

${ }^{21}$ As Nietzsche $(1967,38)$ has it: thoughts befall us, they affect us, and we need to resort to further thoughts to capture their meaning (Krasmann 2019).

${ }^{22}$ It was not until 1865 that the tiny houses in front of Notre-Dame de Paris were removed and the cathedral received today's forecourt (Schwarte 2009: 182).

${ }^{23}$ A. Nossiter, (2019, 16 April). In Aftermath of NotreDame Fire, Macron Urges Unity in Fragmented Nation. New York Times. Retrieved from https://www.nytimes. com/2019/04/16/world/europe/notre-dame-fireinvestigation.html

${ }^{24}$ France launches global contest to rebuild NotreDame spire. France24 (2019, 17 April). Retrieved from https://www.france24.com/en/20190417-francelaunch-international-architect-contest-rebuild-notredame-spire.

${ }^{25}$ For the comment see the website of the architectural office: https://www.u-m-a.se/filter/Featured/NOTREDAME.
26 See, for example, E. Palmer (2019, 27 March). Capturing a World of Emptiness: How a team of photographers documented the quiet desolation of cities during the pandemic. New York Times (retrieved from: https:// www.nytimes.com/2020/03/27/reader-center/ insider-virus-photos.html?action=click \&module $=\mathrm{R}$ elatedLinks\&pgtype=Article). It says: 'There is also a reminder: True beauty comes when the builders roam the built.'

\section{Acknowledgements}

The author would like to thank Ludger Schwarte, Christine Hentschel and the anonymous reviewers of this journal for their insightful comments on an earlier version of this article.

\section{Competing Interests}

The author has no competing interests to declare.

\section{Author Information}

Susanne Krasmann is professor of sociology at the Department of Social Sciences, Universität Hamburg. Her work focuses on law and its knowledge; dispositifs of security; the future of algorithms; the power and truth; vulnerability and political theory. She is co-editor of Governmentality: Current Issues and Future Challenges (Routledge, 2010) and The Desire for Truth and the Political, Special Issue of Behemoth. A Journal on Civilisation (2018). She has published in international journals like Cultural Studies, Leiden Journal of International Law, Policing \& Society, Punishment \& Society, Security Dialogue, Surveillance \& Society and Theoretical Criminology.

\section{References}

Adorno, T. W. (2009). Kultur and Culture. Social Text, 27(2 (99)), 145-158. DOI: https://doi. org/10.1215/01642472-2008-028

Ahmed, S. (2010). Happy Object. In M. Gregg \& G. J. Seigworth (Eds.), The Affect Theory Reader (pp. 29-51). Durham, NC: Duke University Press. DOI: https://doi. org/10.1215/9780822393047-001

Ahmed, S. (2014). The Cultural Politics of Emotion. 2nd ed. Edinburgh: Edinburgh University Press.

Arregui, A., Mackenthun, G., \& Wodianka, S. (Eds.) (2018). DEcolonial Heritage: Natures, Cultures, and the Asymmetries of Memory. Münster: Waxmann.

Autenrieth, S. N., \& van Boekel, D. (2019). Zerstörungswut. The Deliberate Destruction of MonuMentality in Ancient and Modern Times. In F. Buccellati, S. Hageneuer, S. van der Heyden \& F. Levenson (Eds.), Size Matters: Understanding Monumentality Across Ancient Civilizations (pp. 157-170). Bielefeld: transcript. DOI: https://doi. org/10.14361/9783839445389-005

Ballantyne, A. (2002). Architecture: A Very Short Introduction. Oxford: Oxford University Press. DOI: https://doi.org/10.1093/ actrade/9780192801791.001.0001

Ballantyne, A. (2005). Architecture Theory: A Reader in Philosophy and Culture. London, New York: Continuum. 
Barshack, L. (2010). The Constituent Power of Architecture. Law, Culture and the Humanities, 7(2), 217-243. DOI: https://doi. org/10.1177/1743872109355549

Barthes, R. (1972). Mythologies. trans. Annette Lavers. New York: Noonday.

Bataille, G. (1998). Architecture [1929]. In M. Richardson (Ed.), Georges Bataille: Essential Writings (pp. 37-8). London: Sage.

Bennett, J. (2010). Vibrant Matter: A Political Ecology of Things. Durham, NC: Duke University Press. DOI: https://doi.org/10.1515/9780822391623

Birrell, K., \& Lindgren, T.(2021). Anthropocenic Pandemic: Laws of Exposure \& Encounter. Critical Legal Thinking. 4 January. Retrieved from https://criticallegalthinking. com/2021/01/04/anthropocenic-pandemic-laws-ofexposure-encounter/

Brosché, J., Legnér, M., Kreutz, J., \& Ijla, A. (2017). Heritage Under Attack: Motives for Targeting Cultural Property During Armed Conflict. International Journal of Heritage Studies, 23(3), 248-260. DOI: https://doi. org/10.1080/13527258.2016.1261918

Butler, J. (2020). The Force of Nonviolence: The Ethical in the Political. London: Verso.

Chakrabarty, D. (2009). The Climate of History: Four Theses. Critical Inquiry, 35(2), 197-222. DOI: https:// doi.org/10.1086/596640

Chandler, D. (2018). Ontopolitics in the Anthropocene: An Introduction to Mapping, Sensing and Hacking. London: Routledge. DOI: https://doi. org/10.4324/9780203703434

Chernilo, D. (2017). The Question of the Human in the Anthropocene Debate. European Journal of Social Theory, 20(1), 44-60. DOI: https://doi. org/10.1177/1368431016651874

Colebrook, C. (2012). Not Symbiosis, Not Now: Why Anthropogenic Change is not Really Human. Oxford Literary Review, 34(2), 185-209. DOI: https://doi. org/10.3366/olr.2012.0041

Colebrook, C. (2014). Death of the PostHuman: Essays on Extinction, Vol. 1. Open Humanities Press with Michigan Publishing. DOI: https://doi.org/10.3998/ ohp.12329362.0001.001

Colebrook, C., \& Weinstein, J. (2017). Preface: Postscript on the Posthuman. In J. Weinstein \& C. Colebrook (Eds.), Posthumous Life. Theorizing Beyond the Posthuman (pp. ix-xxix). New York: Columbia University Press. DOI: https://doi.org/10.7312/wein 17214

Crouch, D. (2015). Affect, Heritage, Feeling. In E. Waterton \& S. Watson (Eds.), The Palgrave Handbook of Contemporary Heritage Research (pp. 177-190). London: Palgrave Macmillan. DOI: https://doi. org/10.1057/9781137293565_11

Deleuze, G., \& Guattari, F. (1994). What is Philosophy? Trans. Hugh Tomlinson \& Graham Burchell. New York: Columbia University Press.

Delitz, H. (2010). Gebaute Gesellschaft. Architektur als Medium des Sozialen. Frankfurt/M: Campus.

Delitz, H. (2018). Architectural Modes of Collective Existence: Architectural Sociology as a Comparative
Social Theory. Cultural Sociology, 12(1), 37-57. DOI: https://doi.org/10.1177/174997551771 8435

Elias, Norbert. (2000). The Civilizing Process: Sociogenetic and Psychogenetic Investigations. Oxford: Basil Blackwell.

Fischer, J. (2017). Gebaute Welt als schweres Kommunikationsmedium der Gesellschaft. Architektur und Religion aus architektursoziologischer Perspektive. In U. Karstein \& T. Schmidt-Lux (Eds.), Architekturen und Artefakte: Zur Materialität des Religiösen (pp. 49-69). Wiesbaden: Springer. DOI: https://doi.org/10.1007/978-3-658-10404-7_3

Foucault, M. (1989). The Order of Things: An Archaeology of the Human Sciences. London, New York: Routledge.

Franconi, F., \& Lixinski, L. (2017). Opening the Toolbox of International Human Rights Law and the Safeguarding of Cultural Heritage. In A. Durbach \& L. Lixinski (Eds.), Heritage, Culture and Rights: Challenging Legal Discourses (pp. 11-34). Oxford: Hart.

Gafijczuk, D. (2013). Dwelling Within: The Inhabited Ruins of History. History and Theory, 52(2), 149-170. DOI: https://doi.org/10.1111/hith.10662

Gillman, D. (2010). The Idea of Cultural Heritage. Cambridge: Cambridge University Press.

Goodman, N. (1978). Ways of Worldmaking. Indianapolis, IN: Hackett.

Grove, J. V. (2014). Ecology as Critical Security Method. Critical Studies on Security, 2(3), 366-369. DOI: https://doi.org/10.1080/21624887.2014.982402

Hammer, L. (2018). Cultural Heritage Protection and Sacred Spaces: Considering Alternative Approaches from Within the Human Rights Framework. Columbia Human Rights Law Review, 49(2), 1-41.

Harries, K. (1997). The Ethical Function of Architecture. Cambridge, MA: MIT.

Harrison, R. (2013). Heritage: Critical Approaches. New York: Routledge. DOI: https://doi.org/10.1080/00293 652.2015.1126632

Harrison, R. (2015). Beyond 'Natural' and 'Cultural', Heritage: Toward an Ontological Politics of Heritage in the Age of Anthropocene. Heritage \& Society, 8(1), 24-42. DOI: https://doi.org/10.1179/2159032X 15Z.00000000036

Hentschel, C., \& Krasmann, S. (2020). Acts of Exposure and their Affective Publics. In C. Hentschel \& S. Krasmann (Eds.), Exposure. Verletzlichkeit und das Politische in Zeiten radikaler Ungewissheit (pp. 15-34). Bielefeld: transcript. DOI: https://doi. org/10.14361/9783839451106-003

Hinderliter, B., Kaizen, W., Maimon, V., Mansoor, J., \& McCormick, S. (Eds.) (2009). Communities of Sense: Rethinking Aesthetics and Politics. Durham, NC: Duke University Press. DOI: https://doi. org/10.1215/9780822390978

Holtorf, C. (2014). Heritage: Public Perceptions. In Smith, C. (Ed.), Encyclopedia of Global Archaeology (pp. 3361-3366). New York: Springer. DOI: https:// doi.org/10.1007/978-1-4419-0465-2_1133 
Hutchison, E. (2016). Affective Communities in World Politics: Collective Emotions after Trauma. Cambridge: Cambridge University Press. DOI: https://doi. org/10.1017/CBO9781316154670

Ingold, T. (1983). The Architect and the Bee: Reflections on the Work of Animals and Men. Man, 18(1), 1-20. DOI: https://doi.org/10.2307/2801762

Ingraham, C. T. (2006). Architecture, Animal, Human: The Asymmetrical Condition. New York: Routledge. DOI: https://doi.org/10.4324/9780203799604

Jones, P. (2020). Architecture, Time, and Cultural Politics. Cultural Sociology, 14(1), 61-79. DOI: https://doi. org/10.1177/1749975520905416

Kalaycioglu, E. (2020). Aesthetic Elisions: The Ruins of Palmyra and the 'Good Life' of Liberal Multiculturalism. International Political Sociology, 14(3), 1-18. DOI: https://doi.org/10.1093/ips/olaa004

Kraemer, S., \& Bredekamp, H. (2013). Culture, Technology, Cultural Techniques: Moving Beyond Text. Theory, Culture \& Society, 30(6), 20-29. DOI: https:// doi.org/10.1177/0263276413496287

Krasmann, S. (2019). Abandoning Humanity? On Cultural Heritage and the Subject of International Law. Law, Culture and the Humanities, 0, 1-17. DOI: https:// doi.org/10.1177/1743872119843609

Kwek, D. H. B., \& Seyfert, R. (2017). Affect Matters: Strolling through Heterological Ecologies. Public Culture, 30(1), 35-59. DOI: https://doi. org/10.1215/08992363-4189155

Lambropoulos, V. (2001). On the Notion of the Tragedy of Culture. In J. P. I. Arnason \& P. Murphy (Eds.), Agon, Logos, Polis: The Greek Achievement and its Aftermath (pp. 234-253). Stuttgart: Steiner. DOI: https://doi. org/10.1093/cr/52.2.400

Latour, B. (2005). From Realpolitik to Dingpolitik. In B. Latour \& P. Weibel (Eds.), Making Things Public (pp. 14-44). Cambridge, MA: MIT. DOI: https://doi. org/10.1007/978-3-531-92056-6_48

Latour, B. (2013). An Inquiry Into Modes of Existence. Cambridge, MA: Harvard University Press.

Lemke, T. (2015). New Materialisms: Foucault and the 'Government of Things'. Theory, Culture \& Society, 32(4), 3-25. DOI: https://doi.org/10.1177/0263276 413519340

Lostal, M. (2017a). The Misplaced Emphasis on the Intangible Dimension of Cultural Heritage in the $\mathrm{Al}$ Mahdi Case at the ICC. Inter Gentes, 1(2), 45-58.

Lostal, M. (2017b). International Cultural Heritage Law in Armed Conflict: Case Studies of Syria, Libya, Mali, the Invasion of Iraq, and the Buddhas of Bamiyan. New York: Cambridge University Press. DOI: https://doi. org/10.1017/9781316718414

Nietzsche, F. [1967] [1885] Posthumous Fragments 38(1), in Digital Critical Edition of the Complete Works and Letters (based on the critical text by $\mathrm{G}$. Colli and M. Montinari, ed. P. D'Iorio). Berlin: de Gruyter. Retrieved from http://www.nietzschesource. org/\#eKGWB/NF-1885,38

Philippopoulos-Mihalopoulos, A. (2017). Critical Environmental Law as Method in the Anthropocene.
In A. Philippopoulos-Mihalopoulos \& V. Brooks (Eds.), Research Methods in Environmental Law: A Handbook (pp. 131-155). Elgaronline. DOI: https:// doi.org/10.4337/9781784712570

Povinelli, E. A. (2016). Geontologies: A Requiem to Late Liberalism. Durham, NC.: Duke University Press. DOI: https://doi.org/10.1215/9780822373810

Rothe, D. (2020). Governing the End Times? Planet Politics and the Secular Eschatology of the Anthropocene. Millennium: Journal of International Studies, 48(2), 143-164. DOI: https://doi. org/10.1177/0305829819889138

Ruskin, J. (1849). The Seven Lamps of Architecture. Retrieved from http://www.victorianweb.org/ authors/ruskin/7lamps/1.html. DOI: https://doi. org/10.2307/20646641

Schäfer, H. (2016). 'Outstanding Universal Value'. Die Arbeit an der Universalisierung des Wertvollen im UNESCO-Welterbe. Berlin Journal für Soziologie, 26, 353-375. DOI: https://doi.org/10.1007/s11609-0170329-3

Scheidecker, G. (2019). Attachment. In J. Slaby \& C. von Scheve (Eds.), Affective Societies: Key Concepts (pp. 73-84). Abingdon: Routledge. DOI: https://doi. org/10.4324/9781351039260-6

Schwarte, L. (2009). Philosophie der Architektur. München: Fink. DOI: https://doi.org/10.30965/9783846747919

Schwarte, L. (2015). Gründen und Abreißen. In J. Gleiter \& L. Schwarte (Eds.), Architektur und Philosophie: Grundlagen. Standpunkte. Perspektiven (pp. 21-38). Bielefeld: transcript. DOI: https://doi.org/10.14361/ transcript.9783839424643

Seitter, W. (2002). Physik der Medien: Materialien, Apparate, Präsentierungen. Weimar: VDG.

Silverman, H. (2015). Heritage and Authenticity. In E. Waterton \& S. Watson (Eds.), The Palgrave Handbook of Contemporary Heritage Research (pp. 69-88). New York, Basingstoke, Hampshire: Palgrave Macmillan. DOI: https://doi.org/10.1057/9781137293565_5

Simmel, G. (1958). Two Essays: The Handle and The Ruin. The Hudson Review, 11(3), 371-385. DOI: https://doi. org/10.2307/3848614

Simmel, G. (1968). On the Concept and the Tragedy of Culture [1911]. In G. Simmel (Ed.), trans. K. P. Etzkorn, The Conflict in Modern Culture and Other Essays (pp. 27-46). New York: Teachers College Press.

Smith, A. T. (2011). Archeologies of Sovereignty. Annual Review of Anthropology, 40, 415-432. DOI: https:// doi.org/10.1146/annurev-anthro-081309-145754

Stoler, A. L. (2016). Duress: Imperial Durabilities in Our Times. Durham, NC: Duke University Press. DOI: https://doi.org/10.1111/amet.12567

Trimm, R. (2018). Heritage as Trope: Conceptual Etymologies and Alternative Trajectories. International Journal of Heritage Studies, 24(5), 465-476. DOI: https://doi.org/10.1080/13527258.2017.1393446

Tsing, A. L. (2015). The Mushroom at the End of the World. On the Possibility of Life in Capitalist Ruins. Princeton, NJ: Princeton University Press. DOI: https://doi. org/10.2307/j.ctvc77bcc 
Turpin, E. (Ed.) (2013). Architecture in the Anthropocene: Encounters Among Design, Deep Time, Science and Philosophy. Ann Arbor, MI: Michigan Publishing. DOI: https://doi.org/10.3998/ohp.12527215.0001.001

Vatter, M., \& de Leeuw, M. (2019). Human Rights, Legal Personhood and the Impersonality of Embodied Life. Law, Culture and the Humanities (pp. 1-20). DOI: https://doi.org/10.1177/1743872119857068

Veyne, P. (1988). Conduct Without Belief and Works of Art Without Viewers. Diogenes, 36(143), 1-22.
DOI: 4301

Weizman, E. (2014). Introduction: Forensis. In Forensic Architecture (Ed.) Forensis: The Architecture of Public Truth (pp. 9-32). Berlin: Sternberg Press.

Weizman, E., \& Herscher, A. (2011). Architecture, Violence, Evidence. Future Anterior, 8(1), 110-123. DOI: https://doi.org/10.1353/fta.2011.0002

Whatmore, S. (2002). Hybrid Geographies: Natures Cultures Spaces. London: Sage.

How to cite this article: Krasmann, S. (2021). Architecture in the Anthropocene: The Notre-Dame de Paris Fire and the 'Force' of 'Culture'. Anthropocenes - Human, Inhuman, Posthuman, 2(1): 1. DOI: https://doi.org/10.16997/ahip.929

Submitted: 08 June $2020 \quad$ Accepted: 31 October $2020 \quad$ Published: 17 March 2021

Copyright: ( $) 2021$ The Author(s). This is an open-access article distributed under the terms of the Creative Commons Attribution 4.0 International License (CC-BY 4.0), which permits unrestricted use, distribution, and reproduction in any medium, provided the original author and source are credited. See http://creativecommons.org/licenses/by/4.0/.

W Anthropocenes - Human, Inhuman, Posthuman is a peer-reviewed open access journal published by University of Westminster Press. 